\section{Kastamonu Eğitim Dergisi Kastamonu Education Journal}

Eylül 2019 Cilt:27 Sayı:5

kefdergi.kastamonu.edu.tr
Başvuru Tarihi/Received: 04.09.2018

Kabul Tarihi/Accepted: 17.12.2018

DOI: $10.24106 /$ kefdergi.3324

\title{
Öğretmenlerin İş Doyum Düzeylerinin Örgütsel Güven Algılarını Yordaması: Regresyon Analizi Çalışması ${ }^{1}$
}

\section{Prediction of Level of Job Satisfaction of Teachers on Perception of Organizational Trust of Teachers: Study of Regression Analysis}

\section{Öz}

\author{
Nurhayat ÇELEBi², Ramazan Şamil TATIK
}

Bu araştırmanın amacı, öğretmenlerin "iş doyum düzeyleri" ile "örgütsel güven algıları" arasındaki ilişkiyi bazı değişkenler açısından (cinsiyet, yaş, branş ve kıdem) incelemektir. Araştırma, ilişkisel tarama modelinde yürütülmüştür. Araştırmanın çalışma grubu, İstanbul'a bağlı Avcılar ve Bakırköy ilçelerindeki dokuz lisede çalışan 198 öğretmenden oluşmaktadır. Bu araştırmada, "Minnesota İş Doyumu Ölçeği” ile "Örgütsel Güven Ölçeği” kullanılmıştır. Verilerin çözümlenmesinde Pearson Korelasyon Analizi, Basit Regresyon Analizi ve Çoklu Regresyon Analizi yapılmıştr.Regresyon analizi sonuçlarına göre; İçsel ve dışsal iş tatmini faktörlerinin öğretmenlerin örgütsel güvenlerinin anlamlı yordayıcıları olduğu görülmüştür. Diğer taraftan cinsiyet, yaş ve branş değişkenlerinin öğretmenlerin iş doyumu puanlarını yordamalarına ilişkin regresyon analizi sonuçları anlamsız bulunmuştur. Ancak kıdem iş doyumunun yordayıcısı olarak çok az bir etkiye sahiptir. Bunun yanında cinsiyet, yaş, branş ve kıdem değişkenleri bir arada; öğretmenlerin örgütsel güven puanlarını anlamlı düzeyde yordamaktadır. Bu araştırmanın sonuçlarına göre, iş doyumu ile örgütsel güven arasında pozitif ve oldukça yüksek düzeyde anlamlı bir ilişki saptanmıştır.

\section{Anahtar Kelimeler: algı, iş tatmini, örgütsel güven.}

\section{Abstract}

The purpose of this study is to analyze the correlation between "the level of job satisfaction" and "the perception of organizational trust" of teachers' in terms of some variables (gender, age, branch and seniority). The relational survey method was used. The study group consists of 198 teachers working in nine high schools in Avclar and Bakırköy districts connected to İstanbul by random sampling. In this research, "Minnesota Job Satisfaction Scale" and "Organizational Trust Scale" were used. Simple regression analysis, multiple regression analysis and correlation analysis were carried out for data analysis. According to the results of regression analysis, it was seen that the factors of internal job satisfaction and external job satisfaction were significant predictors of the organizational trust of teachers. On the other hand, the results of regression analysis of gender, age and branch variables for teachers' job satisfaction scores were found to be insignificant. However, seniority has little effect as a predictor of job satisfaction. Furthermore, gender, age, branch and seniority variables together predicted organizational trust scores of teacher in a meaningful level. According to the results of this research, a meaningful, positive and quite high level of correlation was determined between job satisfaction and organizational trust.

Keywords: perception, job satisfaction, organizational trust.

1. This study is the extended form of the research presented orally in 3rd International Conference on Lifelong Education and Leadership for All. Porto, Portugal in 2017.

2. Karabük Üniversitesi Edebiyat Fakültesi Eğitim Bilimleri Bölümü, Karabük, Türkiye; https://orcid.org/0000-0002-4914-1555

3. Muş Alparslan Üniversitesi Eğitim Fakültesi Eğitim Bilimleri Bölümü, Muş, Türkiye; https://orcid.org/0000-0002-6727-8264

Attf / Citation: Çelebi, N. \& Tattk, R. Ş. (2019). Prediction of Level of Job Satisfaction of Teachers on Perception of Organizational Trust of Teachers: Study of Regression Analysis. Kastamonu Education Journal, 27(5), 2103-2114. doi:10.24106/kefdergi.3324 


\section{Extended Abstract}

Organizational trust and job satisfaction are the most discussed and researched issues in educational administration. Because these two concepts are important factors that increase employee performance and organizational efficiency. Although job satisfaction is often addressed in connection with motivation, it does not have the same meaning as motivation. Motivation is related to the individual being willing and productive while job satisfaction is mostly related to attitudes and internal situations (Akçamete, Kaner and Sucuoğlu, 2001; Bökeoğlu and Yılmaz, 2008; Çetinkanat, 2000; Davis, 1977; Dinham and Scott, 1996; Karaköse and Kocabaş, 2006; Mullins and Christy, 2010; Özdayı, 1990; Robbins, 1986; Sancar, 1996).

Job dissatisfaction is explained by the tension and frustration created by the inability of the employee to find expectations. Interpersonal (manager and colleague relations) and institutional factors (managerial policies) such as the inconvenience of work conditions, weakness of social relations among workers, excess of work load and role behaviors create tension in people and decrease in person's morale. Organizational trust is explained as the feeling that workers are safe and supported (Özler and Yıldıım, 2015). Research on job satisfaction and perception of organizational trust is a question that maintains its importance in terms of both employees and organizations.

Purpose of the Study:The purpose of this study is to analyze the correlation between "the level of job satisfaction" and "the perception of organizational trust" of teachers' in terms of some variables (gender, age, branch and seniority). In order to achieve this aim, the following questions were asked:

1) What is the relationship level between teachers' job satisfaction and organizational trust?

2) Are job satisfaction levels of teachers a predictor of organizational trust levels?

3) Are gender, age, branch and seniority predictors of job satisfaction?

4) Are gender, age, branch and seniority predictors of organizational trust?

Method: The relational survey method was used. The study group consists of 198 teachers working in nine high schools in Avcılar and Bakırköy districts connected to İstanbul by random sampling. In this research, "Minnesota Job Satisfaction Scale" and "Organizational Trust Scale" were used. Minnesota Job Satisfaction Scale consists of 20 items and Organizational Trust Scale consists of 21 items. Alpha reliability coefficient of Minnesota Job Satisfaction Scale is 0,89 and Alpha reliability coefficient of Organizational Trust Scale is 0,94 . Simple regression analysis and multiple regression analysis were carried out for data analysis.

Findings: In the multiple regression analysis performed, internal job satisfaction and external job satisfaction are significant predictors of the organizational trust of teachers $(p<, 001)$. It can be stated that $17 \%$ of total variance related to organizational trust is explained by internal job satisfaction and $33 \%$ by external job satisfaction.

The results of regression analysis of teachers' gender, age, branch and seniority variables as predictors of job satisfaction scores were found to be insignificant $(\mathrm{R}=, 212, \mathrm{R} 2=, 05, \mathrm{~F}=2,267, \mathrm{p}>, 05)$. For this reason, the regression model is rejected.

In the simple regression analysis, it is seen that the teachers' seniority status is a significant predictor of job satisfaction. It can be stated that $2 \%$ (very little) of total variance related to job satisfaction explained with seniority $(t=2,12, p<, 05)$.

The results of regression analysis of teachers' gender, age, branch and seniority variables as predictors of organizational trust scores were found to be significant $(R=, 266, R 2=, 07, F=3,668, p<, 05)$. These four variables account for $7 \%$ of the total variance. The job satisfaction prediction ability of the branch variable was found to be statistically significant at the level of $15 \%$ and $p<0.05(t=2,110, p=, 036)$. The job satisfaction prediction ability of the seniority variable was found to be statistically significant at $22 \%$ and $t=2,229, p=, 027$.

Results and Conclusions: The results of this study, which examine the effects of teachers' job satisfaction levels on organizational trust, show that job satisfaction has a positive effect on organizational trust. On the other hand, it was determined that teachers 'job satisfaction sub-dimensions predict teachers' organizational trust sub-dimension significantly. According to the results of the research; internal and external factors, which are important determinants of job satisfaction, are important predictors of organizational trust.

In other researches, positive linear relationships were observed between organizational trust and job satisfaction; it was determined that job satisfaction affects organizational trust in some studies and organizational trust affects job satisfaction in others (Gökalp, Kaya, Angay and Akgün, 2015; İşcan and Sayın,2010; Koç and Yazıcıoğlu, 2011; Tekingündüz, Aydın, Polat, 2014; Yazıcıoğlu, 2009). Aslanakutlu (2002), in his study, stated that organizational trust enhances organizational performance and that organizational trust should be established for providing efficiency and effectiveness. In the study of Yildiz (2013), it was stated that the level of trust of the teachers in the principal and organization was moderate, and the trust in the school was higher than the trust in principal in the study. As the teachers' trust in the school principal increases, the job satisfaction also increases and the positive communication between the school principal and the teachers affects teachers' job satisfaction positively.

In this study, the results of regression analysis of teachers' gender, age and branch variables as predictors of job satisfaction scores were found to be insignificant. The seniority variable was found to be an important predictor of organizational trust.

In other researches conducted according to teacher opinions, it was determined that the level of trust in colleagues and principal was high and the level of trust in students and parents was moderate (Babaoğlan 2016a; Babaoğlan, 2016b; Babaoğlan 2016c). Bökeoğlu and Yilmaz (2008) also found similar findings in the research conducted on teachers working in primary schools. Teachers have more trust in their principals, then their colleagues. In the study conducted by Baş and Şentürk (2011), on the contrary, it was found that the teachers trusted in their colleagues most and then the principals. Memduhoğlu and Zengin (2011) found that teachers have a moderate level of trust in the principals in their school.

| Kastamonu Eğitim Dergisi, 27(5), 2019| 


\section{Introduction}

\section{Job Satisfaction}

In the twenty-first century, post-modern organizational paradigms are shaped around concepts such as governance, cooperation, job satisfaction and competition. Organizational trust and job satisfaction are also the most discussed and researched issues in educational administration. Because these two concepts are important factors that increase the work performance and organizational productivity of employees (Akçamete, Kaner and Sucuoğlu, 2001; Altunay and Esen, 2017; Bökeoğlu ve Yılmaz, 2008; Davis, 1977; İşcan and Sayın, 2010; Karaköse and Kocabaş, 2006; Omarov, 2009; Robbins and Judge, 2017).

Although job satisfaction is often addressed in connection with motivation, it does not have the same meaning as motivation. Motivation is related to the individual being willing and productive while job satisfaction is mostly related to attitudes and internal situations. In other words, motivation involves the emotional adaptations that the employee needs to fulfill the role that the job requires in the workplace. For example; sense of personal accomplishment and appreciation is a concept that interests the job satisfaction. Therefore, the positive attitude of the individual towards his work indicates his job satisfaction; whereas the negative attitude indicates his job dissatisfaction (Mullins and Christy, 2010; Vroom, 1964).

Locke (1976) describes job satisfaction as behaviors and reactions to one's job or organizational goals related to the job, and the satisfactory or positive emotions towards achieving these goals. Locke also emphasized the effects of the way employees perceive these conditions, both external and internal, depending on the workplace conditions. According to this, workers who set difficult goals to reach have higher performance and effort than others.

On the other hand, in relation to job satisfaction, the theory developed by Frederick Herzberg (1959) assessed job satisfaction and dissatisfaction factors in two different forms. He named these factors as motivator and hygiene factors. According to Herzberg, hygiene factors do not provide job satisfaction, but they have a preventive structure for job satisfaction and these factors include control. These include cases involving the conduct of work such as "management, supervision, working conditions, wages, manager-subordinate relations, company policy and management, work safety". Satisfaction need in hygiene factors prevents bad performance and dissatisfaction. Motivation factors are motivators for individual such as "self-realization, success, recognition, work itself, responsibility and progress", direct job-related variables that reveal their performance and creativity. These lead to positive work attitudes to meet the need for self-realization. Positive attitudes towards work have been observed to affect motivation. It has been revealed in the studies that the level of performance of employees has a significant effect on job satisfaction (Herzberg, Mausner and Snyderman, 2010; Luthans, 1992; Mullins and Christy, 2010:264-265; Stello, (t.y); Syptek, Marsland and Ulmer, 1999). On the other hand, factors such as organizational climate, organizational trust and organizational culture are seen as important determinants of job satisfaction. The negative perception of these factors leads to the feeling of dissatisfaction with the work and to negative feelings such as boredom, unwillingness, withdrawal from work, work transfer, escape from work (Vangel, 2011).

Job dissatisfaction is explained by the tension and frustration created by the inability of the employee to find expectations. Interpersonal (manager and colleague relations) and institutional factors (managerial policies) such as the inconvenience of work conditions, weakness of social relations among workers, excess of work load and role behaviors create tension in people and decrease in person's morale. As a result, there are disadvantages such as decline in production, deterioration in quality, increase in complaints, absenteeism, increase in labor transfer, misuse of time, disciplinary relaxation, increased tendency to leave work and deterioration in industrial relations (Asunakutlu, 2002:3; Batgün and Şahin, 2006: 33; Cumming 1968; Telman, 1988:101-102; Tett and Meyer, 1993:259-293).

Internal factors are "activity, freedom, change, social status, conscience, authority, ability, responsibility, creativity, appreciation and success". External factors are "manager-person, manager-technical work, social assistance, management policy, payments, promotion, working conditions, cooperation". The internal factors are the motivating individual factors that lead to job satisfaction. The external factors are hygiene factors as Herzbeg expresses.

Many studies have been conducted in the public and private sectors regarding job satisfaction in our country. Studies carried out in the field of education are mostly studies in which the job satisfaction of teachers and administrators is examined according to various variables. Most of the researches on job satisfaction are studies examining the relationship between job satisfaction and organizational stress, burnout, commitment to work, organizational climate, organizational citizenship. In addition, in many of these studies, the effects of various variables such as the quality of 
the job, the salary system, the way in which the awards are given, promotion opportunities, work safety, working conditions, relationships among colleagues, supervision and management style, nature of work, social rights, communication, personality traits of employees, gender, duration of work, which are known as determinants of job satisfaction, were investigated (Akçamete, Kaner and Sucuoğlu, 2001; Balcı, 1985; Currivan, 1999:495-524; Çetinkanat, 2000; Eğinli, 2009; Karaköse and Kocabaş, 2006; Özdayı, 1990; Yavuz and Karadeniz, 2009; Yılmaz, Karahan, 2009).

This study is limited to nine high schools in Bakırköy and Avcılar districts in İstanbul with 198 teachers working and Minnesota Job Satisfaction Scale and Organizational Trust Scale were used to collect data.

\section{Organizational Trust}

Today's organizations are looking for ways to enhance their own effectiveness to better analyze their environment and protect their competitive advantage. According to Mishra (1996), organizational trust depends on the belief that other individuals and groups or organizations are talented, open, honest, and credible, depending on organizational culture and other relationships (akt. Polat, 2009:10). Organizational trust is also explained as the feeling that workers are safe and supported (Özler and Yıldırım, 2015). It is suggested that the concepts of trust and mistrust in the literature are used as the opposite of each other, but it is suggested that there are different dimensions from less to more. From a traditional point of view, distrust represents good, and insecurity represents bad, the two opposite groups. Trust is a concept that also includes optimist expectations in spite of risk taking, uncertainty and possibility of damage. And distrust is expressed as "with the reason that organization's employees cannot establish positive relationships with other employees, the effect of this situation on physical and mental health personally"(Omedei and McLennan, 2000). When the level of trust is high, the workers have an expectation that they will be treated positively. They are willing to remain vulnerable because of this trust. In cases where the level of distrust is high; There is a reason why the workers expect to be treated negatively, and therefore the person has to be alert and cautious (Polat, 2009:50-51).

Shockley-Zalabak, Ellis and Winograd (2000) define organizational trust as a whole of positive expectations and beliefs, depending on the behaviors and intentions of individuals (staff, management) according to organizational role distributions, organizational relationships, expectations, and organizational dependencies. Wech (2002) states that organizational trust is an important element that plays a role in the implementation process of organizational systems. When employees feel that the right decisions are made in the organization, they are more responsive to the decisions taken by the organization. In this way, the trust in the organization affects the organizational commitment and beliefs of people, depending on mutual communication in organizations (Wech, 2002:354). The relationship between organizational trust and organizational climate has a partial mediation role in job satisfaction. Studies show that the high level of workers is closely related to job satisfaction and has an important effect on the formation of organizational climate. The perception of organizational trust and the work environment play an important role in increasing the trunt of employees in the organization (Avram, lonescu and Mincu, 2015). Tan and Tan (2000: 241) have found that organizational trust increases organizational commitment, trust in the manager affects employee satisfaction, and motivation to exhibit innovative behavior. In the literature studies, Tanner (2007: 63) stated that there was a strong positive relationship between organizational trust and job satisfaction, and that job satisfaction levels increased as the level of employees' organizational commitment and organizational trust increased, in particular there is strong interaction between organizational trust and job satisfaction and organizational commitment.

Research on job satisfaction and perception of organizational trust is a question that maintains its importance in terms of both employees and organizations. It is increasingly important to assume that in the traditional structure of Turkey, the assumption that the trust of teachers in their principals is an important determinant is becoming increasingly important in explaining teachers' commitment to their schools and their satisfaction with their job. In this context, the aim of the research is to examine the relationship between job satisfaction and organizational trust according to various variables (gender, age, branch and seniority). In order to achieve this aim, the following questions were asked:

1) What is the relationship level between teachers' job satisfaction and organizational trust?

2) Are job satisfaction levels of teachers a predictor of organizational trust levels?

3) Are gender, age, branch and seniority predictors of job satisfaction?

4) Are gender, age, branch and seniority predictors of organizational trust? 


\section{Method}

\section{Research Model}

This research is a descriptive study in the relational survey method. In the research, the relationship between job satisfaction levels of teachers and organizational trust levels was examined. The relational survey method is a research method aimed at determining the presence or degree of covariance between two or more variables (Creswell, 2017; Karasar, 1999).

\section{Study Group}

The study group of this research consists of 198 teachers in 9 high schools in Avcılar and Bakırköy districts in Istanbul affiliated to the Ministry of National Education in the academic year 2014-2015.

When analyzed according to the demographic variables of the participants, $123(62.1 \%)$ were female and $75(37.9 \%)$ were male. According to age, there are 100 (50.5\%) in the age range of 20-30 years, $69(34.8 \%)$ in the age range of 31-40 years and $29(14.6 \%)$ in the age range of over 41 years. According to professional experience, the teachers who worked for $1-10$ years are $128(64.6 \%), 61(30.8 \%)$ in the range of $11-20$ years and $9(4.5 \%)$ in the range of over 21 years. According to the branch status, $86(43.4 \%)$ of the teachers were classroom teachers, $34(12.2 \%)$ were social studies-Turkish teachers, 19 (9.6\%) were science and mathematics teachers and 59 (29.8\%) were teachers of other branches.

\section{Data Collection Tools}

Two scales were used in this study. "Minnesota Job Satisfaction Scale" from these scales is the short form of the Minnesota Satisfaction Questionnaire (MSQ). Dawis, Weiss, England and Lofquist (1967) combined the items related to satisfaction consisting of internal and external factors from Minnesota Satisfaction Questionnaire's long form (100 items), making it a 20-item scale. The scale has two dimensions. Internal factors are "activity, freedom, change, social status, conscience, authority, ability, responsibility, creativity, appreciation and success". External factors are "manager-person, manager-technical work, social assistance, management policy, payments, promotion, working conditions, cooperation". As you can see, the internal factors are the motivating individual factors that lead to job satisfaction. The external factors are hygiene factors as Herzbeg expresses.

The validity studies of the Minnesota Satisfaction Questionnaire were carried out by Baycan (1985) and the reliability studies by Özdayı (1990). In the study of Özdayı (1990), the reliability coefficient of the scale was 0.87; and the reliability coefficient of the scale in this study was found to be 0.89 . The lowest score that can be taken from the scale items is 20 , and the highest score is 100 . One of the issues discussed on job satisfaction is whether job satisfaction is one-dimensional or multi-dimensional (Aşan and Özyer, 2008: 138). In this study, Minnesota Job Satisfaction Scale was accepted as multi-dimensional.

The 21 item "Organizational Trust Scale" developed by Daboval, Comish and Swindle and Gaster (1994) was adapted to Turkish and used by Kamer (2001). Both job satisfaction and trust scale score values are as follows. Both scales are in the 5-Likert type and are ranked from 1 (I absolutely do not agree) to 5 (I totally agree). The average score values of this scale are; 5.00-4.20 "I totally agree", 4.20-3.41 "I agree", 3.40-2.61 "I partially agree", 2.60-1.81 "I do not agree" and 1.80-1.00- "I absolutely do not agree". The lowest and highest scores that can be taken from the scales are 21-105.

In Kamer's (2001) study, the reliability of the Organizational Trust Scale Cronbach's Alpha was 0,96; and in this study it was 0.94 . In the factor analysis conducted by Kamer (2001), since the factor load of any item did not fall below 0.45 , all items on the test scale were taken to the original scale. As a result of the application of Polat (2007), Cronbach's Alpha coefficient of the trust scale of the study was 0.96 . In the factor analysis, all the items were collected in one factor and all the items were taken into consideration since the factor loads were higher than 0.45 . Factor analysis was not used again in this study. The factor structure of Polat's (2007) research was preserved, and the scale was treated as a one-factor structure.

Questionnaire forms consisting of the sets of questions including the demographic characteristics of the participants together with the Job Satisfaction Scale and the Organizational Trust Scale were conducted by the researchers themselves in the determined schools. While some of the scales could be collected on the day of the application, some scales could be collected on the following days. Since 9 of the 207 questionnaires that arrived from 207 participants had incomplete marked items, these 9 questionnaires were not included in the analysis and the analysis was carried out through 198 questionnaires. 


\section{Analysis of Data}

The data obtained from the questionnaires were analyzed by the researchers using the SPSS program. To conduct the regression analysis, it was checked whether variables showed normal distribution and the relation between the variables was linear. Independent variables were gender, age, branch and seniority; dependent variables were job satisfaction and organizational trust. Simple Regression Analysis and Multiple Regression Analysis were used to determine the independent variables' level of predicting the dependent variables. In interpreting the regression analyzes, the standardized Beta coefficients and the t-test for their significance and one-way ANOVA results were taken into account.

\section{Findings}

\section{Averages and Standard Deviations of the Job Satisfaction Scale}

The averages and standard deviations of the subscales related to the analysis of the teachers' job satisfaction levels and the correlation coefficients are given in Table 1.

Table 1. Average and Standard Deviations and Correlation Coefficients of Teachers Related to Job Satisfaction and Organizational Trust Factor Dimensions

\begin{tabular}{lcccc} 
& $\bar{X}$ & s.s & External Job Satisfaction & Organizational Trust \\
Internal Job Satisfaction & 3,71 & 0,63 &, $665(* *)$ &, $407\left({ }^{* *}\right)$ \\
External Job Satisfaction & 3,12 & 0,71 & &, $571(* *)$ \\
Organizational Trust & 3,77 & 0,82 & & \\
\hline
\end{tabular}

${ }^{* *} \mathrm{p}<0,001, * \mathrm{p}<0,05$

As shown in Table 1, the average of "Internal Job Satisfaction" dimension of the Job Satisfaction Scale $(=3,71)$ shows the option of "I agree" and the average of "External Job Satisfaction" dimension of Job Satisfaction Scale $(=3,12)$ shows the option of "I partially agree". These averages show that internal job satisfaction level that affects teachers' job satisfaction is at a fairly good level, but external satisfaction level is low. The average of the organizational trust scale also shows on the option of "I agree" $(=3,77)$. This result shows that teachers trust in the school where they work.

Positive significant relationships were found between teachers' job satisfaction sub-dimensions and organizational trust $p<, 001$ level). The relationship at the highest level is the relationship between "internal job satisfaction" and "external job satisfaction" $(r=, 665 ; p<, 001)$. "The relationship between external job satisfaction and organizational trust was calculated as $(r=, 571 ; p<, 001)$. The lowest level of relationship was found between "internal job satisfaction" and "organizational trust" $(r=, 407 ; p<, 001)$.

Table 2. Results of multiple Linear Regression Analysis on the Predictions of "Organizational Trust" of Sub-Dimensions of "Internal Job Satisfaction" and "External Job Satisfaction" for the "Job Satisfaction Scale"

\begin{tabular}{|c|c|c|c|c|c|c|c|}
\hline $\begin{array}{l}\text { Variables } \\
\text { (Constant) } \\
\text { nternal Job Satisfaction } \\
\text { External Job Satisfaction }\end{array}$ & $\begin{array}{c}\mathbf{R} \\
, 407 \\
, 571\end{array}$ & $\begin{array}{l}\mathbf{R}^{\mathbf{2}} \\
17 \\
, 33 \\
\end{array}$ & $\begin{array}{c}\mathbf{F} \\
38,877 \\
94,736\end{array}$ & $\begin{array}{c}\text { B } \\
1,621\end{array}$ & $\begin{array}{l}\text { Beta } \\
, 407 \\
571\end{array}$ & $\begin{array}{c}\mathbf{t} \\
6,235 \\
9,733\end{array}$ & $\begin{array}{c}\mathbf{P} \\
000 \\
000 \\
\end{array}$ \\
\hline
\end{tabular}

According to Table 2, in the multiple regression analysis performed, internal job satisfaction and external job satisfaction are significant predictors of the organizational trust of teachers $(p<, 001)$. It can be stated that $17 \%$ of total variance related to organizational trust is explained by internal job satisfaction and $33 \%$ by external job satisfaction.

Table 3. Results of Multiple Regression Analysis on the Prediction of Job Satisfaction (Enter Method)

\begin{tabular}{lllll}
\hline Predictive Variables & $B$ & Beta & $t$ & $P$ \\
Constant & 65,886 & - & 19,840 &, 000 \\
Gender & $-1,199$ &,- 049 &,- 696 &, 487 \\
Age & $-1,865$ &,- 119 & $-1,214$ &, 226 \\
Branch &, 998 &, 109 & 1,521 &, 130 \\
Seniority & 4,441 &, 223 & 2,255 &, 025 \\
$\mathrm{R}=, 212 \mathrm{R} 2=, 05$ & & & & \\
$\mathrm{~F}=2,267 \mathrm{p}=, 063$ & & & & \\
\hline
\end{tabular}

According to Table 3, the results of regression analysis of teachers' gender, age, branch and seniority variables (dummy variables) as predictors of job satisfaction scores were found to be insignificant $(R=, 212, R 2=, 05, F=2,267$, $p>, 05)$. For this reason, the regression model is rejected. Here, since the "seniority" variable is the predictor of job satisfaction alone, the result of simple regression analysis is presented below. 
Table 4. Results of Simple Linear Regression Analysis on Teachers' Seniority Related to Job Satisfaction Prediction

\begin{tabular}{lccccccc}
\hline Variables & & & & & & \\
(Constant) & $R$ & $R^{2}$ & $F$ & $B$ & $B e t a$ & $t$ & $P$ \\
Seniority &, 150 &, 02 & 4,504 & 2,978 &, 150 & 2,122 &, 035 \\
\hline
\end{tabular}

According to Table 4; in the simple regression analysis, it is seen that the teachers' seniority status is a significant predictor of job satisfaction. It can be stated that $2 \%$ (very little) of total variance related to job satisfaction explained with seniority $(t=2,12, p<, 05)$.

Table 5. Results of Multiple Regression Analysis on Organizational Trust Prediction

\begin{tabular}{lllll}
\hline Predictive Variables & $B$ & Beta & $t$ & $P$ \\
Constant & 64,850 & - & 14,547 &, 000 \\
Gender & 1,172 &, 035 &, 507 &, 613 \\
Age &,- 835 &,- 039 &,- 405 &, 686 \\
Branch & 1,857 &, 149 & 2,110 &, 036 \\
Seniority & 5,893 &, 218 & 2,229 &, 027 \\
$\mathrm{R}=0,266 \mathrm{R}^{2}=, 07$ & & & & \\
$\mathrm{~F}=3,668 \mathrm{p}=, 007$ & & & & \\
\hline
\end{tabular}

According to Table 5; the results of regression analysis of teachers' gender, age, branch and seniority variables as predictiors of organizational trust scores were found to be significant $(R=, 266, R 2=, 07, F=3,668, p<, 05)$. These four variables account for $7 \%$ of the total variance. The organizational trust prediction ability of the branch variable was found to be statistically significant at the level of $15 \%$ and $p<0.05(t=2,110, p=, 036)$. The job trust prediction ability of the seniority variable was found to be statistically significant at $22 \%$ and $t=2,229, p=, 027)$.

\section{Results, Conclusions and Suggestions}

The results of this study, which examine the effects of teachers' job satisfaction levels on organizational trust, show that job satisfaction has a positive effect on organizational trust. On the other hand, it was determined that teachers 'job satisfaction sub-dimensions predict teachers' organizational trust sub-dimension significantly. According to the results of the research; internal and external factors, which are important determinants of job satisfaction, are important predictors of organizational trust.

In some researches, it was seen that positive linear relationships were observed between organizational trust and job satisfaction (Boyacı, Karacabey and Bozkuş, 2018; Gökalp, Kaya, Angay and Akgün, 2015; İşcan and Sayın, 2010; Koç and Yazıcıoğlu, 2011; Shocley-Zalabak, Ellis and Wigrad, 2000; Tekingündüz, Aydın, Polat, 2014; Yazıcıoğlu, 2009). Aslanakutlu (2002), in his study, stated that organizational trust enhances organizational performance and that organizational trust should be established for providing efficiency and effectiveness. In the study of Yildiz (2013), it was stated that the level of trust of the teachers in the principal and organization was moderate, and the trust in the school was higher than the trust in principal in the study. As the teachers' trust in the school principal increases, the job satisfaction also increases and the positive communication between the school principal and the teachers affects teachers' job satisfaction positively.

Al-Abr row, Ardakani, Harooni and Moghaddam pour et al. (2013) found that organizational trust affects organizational justice, and organizational trust plays an important role as a mediating variable in job commitment, and there was also a significant relationship between the trust in principal and organizational trust. It is therefore often seen that lack of trust in organizations has negative effects on organizational performance. Aftab and Idrees (2012), Platis, Reklitis ve Zimeras (2015) found a positive relationship between job performance and job satisfaction. The research findings are that the teachers' personal performance is important factor affecting job quality and job satisfaction, that the creative climate of the working environment and the management understanding of the principal increase the individual work performance and that teachers who are satisfied with their work are more productive for the organization.

In this study, the results of regression analysis of teachers' gender, age and branch variables as predictors of job satisfaction scores were found to be insignificant. The seniority variable was found to be an important predictor of organizational trust. However, in some studies, there was no significant relationship with the trust dimension of seniority. (Altunay, 2017; Bökeoğlu and Yılmaz, 2008; Omarov, 2009; Yılmaz, 2005). In some studies, it was determined that the effects of different effects (such as professionalism) have a positive effect on the feeling of trust when age increases with seniority (işsan and Sayın, 2010; Polat and Celep, 2008; Stepanova, 2013). Different results have been obtained in the studies conducted with variables such as age, seniority, marital status, gender, organizational training, type of work related to job satisfaction. Akçamete et all. (2001), Boyacı et all (2018); Dinham and Scott (1996), Eğinli (2009), Ergin 
(1997), Gilmer (1966), Kalleberg and Loscocco (1983), Khan (1991); Lee and Wilbur (1985); Omarov (2009); Özdayı (1990); Robbins and Judge (2013); Surada (2015); Şahin (2013); Tunacan and Çetin (2009); Tümkaya (1986); Yücel and Demirel (2013) in this research was found that age had no significant effect on job satisfaction; However, as the professional experience increases, it is seen that the factors such as participation of the employees in the decision-making process and feeling comfortable in the workplace are effective as a result of the increase in the income level of the employees and the increase in the income level, thus increasing the satisfaction of the employees. In some studies, there are also discrepancies between job satisfaction and gender variable According to the situation; in some cases women have more job satisfaction while in some cases men seem to have job satisfaction (Can, Can and Dalaman, 2010; Eğinli, 2009; Karaköse and Kocabaş, 2006; Kumaş and Deniz, 2010; Sancar, 1996; Surada, 2015; Tunacan and Çetin, 2017).

In other researches conducted according to teacher opinions, it was determined that the level of trust in colleagues and principal was high and the level of trust in students and parents was moderate (Babaoğlan 2016a; Babaoğlan, 2016b; Babaoğlan 2016c). Bökeoğlu and Yilmaz (2008) also found similar findings in the research conducted on teachers working in primary schools. Teachers have more trust in their principals, then their colleagues. In the study conducted by Baş and Şentürk (2011), on the contrary, it was found that the teachers trusted in their colleagues most and then the principals. Memduhoğlu and Zengin (2011) found that teachers have a moderate level of trust in the principals in their school.

In the study of Cemaloğlu and Kılınç (2012), it was stated that as the school directos' ethical behaviors were fulfilled, the organizational trust levels of the teachers increased, the mobbing behaviors of the principals decreased and the academic quality increased. In the research conducted by Altaş and Kuzu (2013) and Eren and Hayatoğlu (2011), it was determined that ethical climate has a positive effect on teachers' trust in principals and organization and business performance. That is, as the trust of preschool teachers in the principals increases, individual job performance increases. However, no significant findings were found on the effect of trust in the organization on individual job performance.

Bilge, Akman and Kelecioğlu (2007) found that age and seniority increased the job satisfaction of adacemicians as the title increased. In the study conducted by Şentürk (2011), it was seen that the perceptions of organizational trust did not differ according to the gender and educational status of the teachers, but they differed according to seniority. 1-5-year teachers have the lowest perception of organizational trust. There was a significant difference in total scores between the trust in principal, stakeholders, and organization. However, organizational trust did not have a significant effect on the individual performance of the teachers statistically on the level of trust in their colleagues (Büte, 2011:171). These results are in parallel with the studies on job satisfaction of teachers and principals (Çetinkanat, 2000; Esen, 2001; Heller, Clay and Perkins, 1993). Luthans and Thomas (1987) found that older people did not want change because they could not easily adapt to the changes in technology compared to younger teachers, leading to a reduction in job satisfaction. (Luthans and Thomas 1987: 23-26). Özdayı (1990) did not find a significant relationship between age groups and job satisfaction. In other dimensions of job satisfaction, gender differences were not significant but female teachers' job satisfaction related to social relations was slightly higher than male workers. İscan and Sayın, 2010; Tekingündüz, Aydın and Polat, (2014) found no significant difference in job satisfaction and trust among the age groups. However, as the level of education increased, teachers' job satisfaction and trust increased. Again, in Yazicioglu's (2009) research, it was found that organizational trust, job satisfaction level and intention to leave job were not significantly different in terms of gender, but there was a significant difference in terms of education, age and seniority year.

The average of internal factors related to job satisfaction in this study is higher than the average of external factors. In other words, this dimension is related to "conscience, responsibility, success, recognition, appreciation, creativity" which brings teachers' motivation to the top level. If an organization is pursuing self fulfillment policies for its teachers, the productivity of its teachers is also increasing. This shows that the motivation of teachers has an unusually large influence on job satisfaction. In this study, it was determined that the averages related to external motivation were lower than those of internal motivation. This shows that the items related to Herzberg's hygiene factors (such as working conditions, promotion, salary, vocational assurance, management involvement) were not at the desired level. Kavili, Bulut, Doğan and Tekinbaş (2013), in their study, found that the most striking consequence for job satisfaction in the public sector was the general dissatisfaction with the salary. In Özdayı's study on teachers working in public and private high schools in 1990, it is noteworthy that the fact that the reasons for the insufficiency of salaries and the working conditions are the most stressful situation and led to the dissatisfaction hasn't changed despite the years. Again, Kavili, Bulut, Doğan and Tekinbaş (2013) reported that there was a general dissatisfaction in the promotion system with the increase of obstacles related to the promotion.

It has been proven through the research that the presence of the feeling of trust affects teachers ' work behaviors and their attitudes towards work (Driscoll,1978; Lagace, 1991; Pillai et al., 1999). Tamer (2012) revealed in a study | Kastamonu Eğitim Dergisi, 27(5), 2019| 
on teachers that the organizational trust consists of components such as fulfilling the promises, being honest and not exhibiting opportunistic behavior, and that the components in question were influenced by cognitive, emotional and behavioral processes (Tamer, 2012:344). Karapınar (2015) stated that teachers with a secure attachment and obsessive attachment style had more emotional trust in their principals. On the other hand, the four attachment styles (trust, obsessive preoccupation, dismission and fearful attachment) of the teachers towards the principals were not found to affect cognitive trust. However, a moderate relationship was found between these four styles and the trust in the principal.

In conclusion, the establishment of trust-based relationships in organizations, the trust of teachers as a whole in their principals are related to the belief that the decisions taken are fair, and the high levels of satisfaction. Here, teachers' job satisfaction can be increased by understanding the causes that reveal these positive feelings by the principals. Because whether or not the relationships established by teachers in the organization are based on trust is an element that affects their job satisfaction (İscan ve Sayın, 2010). Teachers' trust in their work, their level of satisfaction with the work and personal talents and skills are also positively affected. The individual's trust in the organization, the senior management and even his colleagues ensures that he has an appropriate natural effort for a goal, he has an interest in his job, he has a high commitment to his job, and a high morale.

Trust of teachers in themselves and others and the job satisfaction cause organizations to perform better and raise success rates. It is closely related to the job satisfaction of the organization teachers that organizations should look safely to the future. In this respect, principals should take precautions to increase the working capacity of the organization by organizing the work environments in a way to raise the motivation, to be fair in the distribution of the tasks for the teachers, to support individual developments of the teachers. Teachers should have more trust in the principals if the principal's expertise, merit and personality characteristics are taken into account for the principal appointments.

Researchers can interview with teachers to get detailed data about organizational trust and job satisfaction. They can develop new and up-to-date scales after analyzing interview data and collect more data from teachers from different cities or countries and compare the findings and results. The correlation between job satisfaction and organizational commitment can also be analyzed. New studies should be conducted to identify different variables affecting job satisfaction and job security of teachers.

\section{References}

Aftab, H., \& Idrees, W. A. (2012). A study of job satisfaction and its impact on the performance in the banking industry of Pakistan. International Journal of Business and Social Science. 3(19), October 2012.

Akçemete, G., Kaner, S. ve Sucuoğlu, B. (2001). Öğretmenlerde tükenmişlik, iş doyumu ve kişilik. Nobel: Ankara.

Al-Abr row, H. A., Shaker Ardakani, M., Harooni, A., \& Moghaddam pour, H. (2013). The Relationship between organizational trust and organizational justice components and their role in job involvement in education. International Journal of Management Academy. Summer, 1(1): 25-41.

Allen, N. J., \& Meyer, J. P. (1990). The measurement and antecedents of affective, continuance and normative commitment to the organization. Journal of Occupational Psychology, 63(1), 1-18. doi:10.1111/j.2044-8325.1990.tb00506.x.

Altaş, S. S. ve Kuzu, A. (2013). Örgütsel etik, örgütsel güven ve bireysel iş performansı arasındaki ilişki: okul öncesi öğretmenleri üzerinde bir araştırma. Elektronik Mesleki Gelişim ve Araştırma Dergisi. 1(2), 29-41.

Altunay, E. (2017). ilköğretim okulu öğretmenlerinin örgütsel güven ve adanmışlık düzeyleri arasında ilişkinin incelenmesi. Milli Eğitim. Sayı: 213, Kış 2017, 37-66.

Arslan, Y. (2009). Kurumsallaşma ve örgütsel güven ilişkisi (Yayımlanmamış Doktora Tezi), Gebze Yüksek Teknoloji Enstitüsü. Sosyal Bilimler Enstitüsü. Gebze.

Aslanakutlu, T. (2002). Örgütsel güvenin oluşturulmasına ilişkin unsurlar ve bir değerlendirme. Muğla Üniversitesi Sosyal Bilimler Enstitüsü Dergisi, Güz, Sayı: 9, 1-13.

Aşan, Ö. ve Özyer, K. (2008). Duygusal bağılık ile iş doyumu ve iş doyumunun alt boyutları arasındaki ilişkileri analiz etmeye yönelik ampirik bir çalışma. Süleyman Demirel Üniversitesi iktisadi ve Idari Bilimler Fakültesi Dergisi, 13(3), 129-151.

Avram, E., lonescu, D., \& Mincu, C. L. (2015). Perceived safety climate and organizational trust: the mediator role of job satisfaction. Procedia Social and Behavioral Sciences. 187, 679-684.

Aziri, B. (2011). Job satisfaction: A Literature Review. Management Research and Practice. 3(4), 77-86.

Babaoğlan, E. (2016a). Improving principal and teacher relationship: Predictive power of school principals' leadership with teachers' organizational trust perception. Educational Planning, 23(2), 7-17.

Babaoğlan, E. (2016b). The predictive power of leadership to the perception of school trust. Universal Journal of Educational Re-search, 4(12A), 124-131.

Babaoğlan, E. (2016c). The predictive power of organizational trust to organizational commitment in elementary and high school teachers. Anthropologist, 24(1), 83-89. 
Balcı, A. (1985). Eğitim yönetiminde iş doyumu. (Yayımlanmamış Doktora Tezi). Ankara Üniversitesi Sosyal Bilimler Enstitüsü. Ankara.

Baş, G. ve Şentürk, C. (2011). illköğretim okulu öğretmenlerinin örgütsel adalet, örgütsel vatandaşlık ve örgütsel güven algıları. Kuram ve Uygulamada Eğitim Yönetimi. 17(1), 29-62.

Batıgün, A. D. ve Şahin, N. H. (2006). İş stresi ve sağlık psikolojisi araştırmalan için iki ölçek: A-tipi kişilik ve iş doyumu, Türk Psikiyatri Dergisi, $17(1)$ : $32-25$.

Baycan, A. (1985). An analysis of several aspects of job satisfaction between different occupational grups. (Yayımlanmamış Yüksek Lisans Tezi). İstanbul Boğaziçi Üniversitesi.

Bilge, F., Akman, Y. ve Kelecioğlu, H. (2007). Öğretim elemanlarının iş doyumlarının incelenmesi. Hacettepe Üniversitesi Eğitim Fakültesi Dergisi. $32,32-41$.

Boyacı, A., Karacabey, M. F. \& Bozkuş, K. (2018). The rol of organizational trust in the effect of leadership of school administrators on job satisfaction of teachers. Kuram ve Uygulamada Eğitim Yönetimi. 24(39). 437-487.

Bökeoğlu, Ö. Ç. \& Yılmaz, K. (2008). ilköğretim okullarında örgütsel güven hakkında öğretmen görüşleri. Kuram ve Uygulamada Eğitim Yönetimi. Bahar. Sayı: 54, 211-233.

Büte, M. (2011). Etik iklim, örgütsel güven ve bireysel performans arasındaki ilişki. Atatürk Üniversitesi iktisadi ve Idari Bilimler Dergisi, Cilt: 25 , Sayı: 1.

Büyüköztürk, Ş. (2013). Veri analizi el kitabı. 13.baskı. Ankara: Pegem A.

Can, S., Şendil, C. \& Dalaman, O. (2010). Sınıf öğretmenlerinin çeşitli faktörlere gore iş doyum düzeyleri. Muğla ili örneği. Selçuk Üniversitesi Ahmet Keleşoğlu Eğitim Fakültesi Dergisi. Sayı: 30, 299-311.

Cemaloğlu, N. \& Kılınç, A. Ç. (2012). İlköğretim okulu yöneticilerinin etik liderlik davranışları ile öğretmenlerin algıladıkları örgütsel güven ve yıldırma arasındaki ilişki. Eğitim ve Bilim. 37(165), 137-150.

Cumming, M. W. (1968). The theory and practice of personnel management. London: Heinemann Ltd.

Currivan, D. B. (1999). The causal order of job satisfaction and organizational commitment in models of employee turnover. Human Resource Management Review, 22(4), 495-524.

Creswell, J. W. (2017). Correlational designs. A. Avcı (Çev.) İstanbul: EDAM.

Çetin, M. (2004). Örgütsel vatandaşlık davranışı. Ankara: Nobel.

Çetinkanat, C. (2000). Örgütlerde güdülenme ve iş doyumu. Ankara: Anı Yayınclık.

Daboval, J., Comish, R., Swindle, B., \& Caster, W. (1994). A trust inventory for small businesses. Small Businesses Symposium, http:/www.sbaer. uca.edu/docs/proceedings /94swi031.txt adresinden 06.06.2014 tarihinde elde edilmiştir.

Dawis, R. V., Weis, D. J., England, G.V., \& Lofquist, L. H. (1967). Manuel for the Minnesota satisfaction questionnaire. University of Minnesota. Industrial Relations Center. Minneopolis.

Demirel, Y. (2008). Örgütsel güvenin örgütsel bağlılık üzerine etkisi. Tekstil sektörü çalışanlarına yönelik bir araştırma. Yönetim ve Ekonomi. Celal Bayar Üniversitesi i.i.B.F. 15(2). 179-194. Manisa.

Dinham,S., \& Scott,C. (1996). Teacher satisfaction motivation and health. ERIC Documents. ED408247.

Driscoll, J. W. (1978). Trust and participation in organizational decision making as predictors of job satisfaction. Academy of Management Journal, 21, 44-56.

Eğinli, A. T. (2009). Çalışanlarda iş doyumu: kamu ve özel sektör çalışanlarının iş doyumuna yönelik bir araştrrma. Atatürk Üniversitesi iktisadi ve idari Bilimler Dergisi, 23(3), 35-52.

Eren, S. S. \& Hayatoğlu, Ö. (2011). Etik iklimin satı̧s elemanlarının iş tutumlarına ve iş performanslarına etkisi: ilaç sektöründe bir uygulama. Zonguldak Bülent Ecevit Üniversitesi Sosyal Bilimler Dergisi, 7(14), 109-128.

Ergin, C. (1997). Bir iş doyumu ölçümü olarak "iş betimlemesi ölçeği”: uyarlama, geçerlik ve güvenirlik çalışması. Türk Psikoloji Dergisi. 12(39). 25-36.

Esen, N. (2001). Beden eğitimi ve spor öğretmeni yetiştiren yükseköğrenim kurumlarında çalışan öğretim elemanlarının iş doyumu düzeylerinin incelenmesi. (Yayımlanmamış Yüksek Lisans Tezi). Bolu: Abant İzzet Baysal Üniversitesi.

Eren, E. (2002). Örgütsel davranış ve yönetim psikolojisi. İstanbul: Beta Basım.

Ferres, N., Connell, J., \& Travaglione A. (2005). The effect of future redeployment on organizational trust. Published online in Wiley. Inter Science. Strategic Change, 14(2), 77-91.

Gilmer, B. \& Von H. (1971). Industrial and organizational psychology. Newyork. McGraw Hill Book Company.

Gökalp, S., Kaya, O., Angay, A., \& Akgün, F. (2015). Öğretmen algılarına göre okul müdürüne güvenin iş doyumu üzerindeki etkisinde lider- üye etkileşiminin aracı rolü. Bitlis Eren Üniversitesi SBE Dergisi. 4(2), 44-70.

Heller, H. W., Clay, R., \& Perkins, V. (1993). The relationship between teacher job satisfaction and principal leadership style. Journal of School Leadership. 3(1), 74-86.

Herzberg, F., Mausner, B., \& Snyderman, B. (2010). The motivation to work (12th ed.). New Brunswick: Transaction Publishers.

İşcan, Ö. F. \& Sayın, U. (2010). Örgütsel adalet, iş doyumu ve örgütsel güven arasındaki ilişki. Atatürk Üniversitesi İktisadi ve Idari Bilimler Dergisi, 24(4), 195-216.

Judge, T. A., Thoresen, C. J., Bono, J. E., \& Patton, G. K. (2001). The job satisfaction- job performance relationship: A qualitative and quantative review. Psyhological Bulletin. 127(3). 376-407. 
Kalleberg, A. L. \& Loscacco, K. A. (1973). Aging values and rewards. Explaining age differences in job satisfaction. American Social Review. Vol. 48.78-90.

Kamer, M. (2001). Örgütsel güvenin örgütsel bağlılı ve örgütsel vatandaşlık davranışlarına etkileri. (Yayımlanmamış Yüksek Lisans Tezi). Marmara Üniversitesi Sosyal Bilimler Enstitüsü, İstanbul.

Karaköse, T. \& Kocabaş, ì. (2006). Özel ve devlet okullarında öğretmenlerin beklentilerinin iş doyumu ve beklentilerinin iş doyumu ve motivasyon üzerine etkileri. Eğitimde Kuram ve Uygulama. 2(1). 3-14.

Karapınar, P. B. (2015). Okul yöneticisine güven: Bağlanma stilleri ile ilişkisi. Hacettepe Üniversitesi Eğitim Fakültesi Dergisi. 30(3), 73-86.

Karasar, N. (1999). Bilimsel araştırma yöntemi. Ankara: Nobel.

Kavili, A. S., Bulut, Z. A., Doğan, O., \& Tekinbaş, F. (2013). Meslek yüksekokullarında çalışan personelin iş doyumu: İzmir meslek yüksekokulu örneği. Elektronik Mesleki Gelişim ve Araşttrma Dergisi. 1(2), 68-80.

Khanifar, H., Moghimi S. M., Jandaghi G. H., \& Zoorandi, N. (2009). The examination of relationship between components of trust and organizational commitment of employees (in the education and agriculture organization of Qom Province. Journal of Public Administration: 1(2): 4-18.

Khan, U.A. (1991). Satisfaction of secondary school administrators with their work.in Pakistan. (Yayınlanmamış doktora tezi). ODTÜ Eğitim Fakültesi. Ankara.

Koç, H. \& Yazıcıoğlu, ì. (2011). Yöneticiye duyulan güven ile iş doyumu arasındaki ilişki: Kamu ve özel sektör karşılaştırması. Doğuş Üniversitesi Dergisi. 12(1), 46-57.

Koçel, T. (2005). İşletme yöneticiliği. İstanbul: Arıkan Basım Yayım.

Korman, A. (1977). Organizational behavior. New Jersey. Prentice Hall.

Kumaş, V. \& Deniz, L. (2010). Öğretmenlerin iş doyum düzeylerinin incelenmesi. M.Ü. Atatürk Eğitim Fakültesi Eğitim Bilimleri Dergisi. Sayı: $32,123-139$.

Lafferty, C., \& Lafferty, B. D. (2001). Trust in organizations. Symposium 6. [AHRD Conference, 20011. PUB DATE 2001-00-00 NOTE 33p. In: Academy of Human Resource Development (AHRD) Conference Proceedings (Tulsa, Oklahoma, February 28-March 4, 2001 ). 1(2); CE 081 829. PUB TYPE Collected Works - General (020) -- Speeches/Meeting Papers (150).

Lagace, R. R. (1991). An exploratory study of reciprocal trust between sales managers and salespersons. Journal of Personel Selling and Sales Management, 11(Spring), 49-58.

Lee, R., \& Wilbur, E. R. (1985). Age, education job tenure, salary, job characteristics and satisfaction: a multivariate analysis. Human Relations. 38(8).781-791.

Locke, E. A. (1969). What is job satisfaction? Organizational behavior and human performance, 4(4), November 309-336.

Locke, E. A. (1976). The nature and causes of job satisfaction in M. D. Dunnette (Ed.). Handbook of Industrial and Organizational Psychology. $1297-1349$.

Luthans, F. (1992). Organizational behavior. New York: Mc Graw-Hill. Inc.

Luthans F., \& Thomas L. T. (1987). The relationship between age and job satisfaction: curvilinear results from an emprical study: A research note. Personel Review, 18(1), 23-26.

Luthans, F., Avolio, B. J., Avey, J. B., \& Norman, S. M. (2007). Positive psychological capital: Measurement and relationship with performance and satisfaction. Personnel Psychology, 60(3), 541-572. doi:10.1111/j.1744-6570.2007.00083.

McAllister, D. J. (1995). Affect- and cognition-based trust as foundations for interpersonal cooperation in organizations. Academy of Management Journal. 3(1), 24-59.

Memduhoğlu, H. B., \& Zengin, M. (2011). Illköğretim okullarında örgütsel güvene ilişkin öğretmen görüşleri. Yüzüncü Yıl Üniversitesi Eğitim Fakültesi Dergisi. 8(1), 211-217.

Mullins, L. J., \& Christy, G. (2010). Management and organisational behaviour. (9th ed.). London: Prentice Hall.

Omarov, A. (2009). Örgütsel güven ve iş doyumu. Dokuz Eylül Üniversitesi. Sosyal Bilimler Enstitüsü. Yayınlanmamış yüksek lisans tezi. İzmir.

Omodei, M. M., \& Mclennan, J. (2000). Conceptualizing and measuring global interpersonal mistrust-trust. Journal Social Psychology, 140 (3), July $279-94$.

Onaran, O. (1981). Çalışma yaşamında güdülenme kuramları. Ankara Üniversitesi Siyasal Bilgiler Fakültesi. Yayın No:470. Ankara.

Öğütveren, Ö. (2007). Örgütsel güvenin ağ düzenekleri içerisindeki analizi: küçük işletmelerde bir uygulama. (Yayımlanmamış doktora tezi). Gazi Üniversitesi Sosyal Bilimler Enstitüsü. Ankara.

Özdayı, N. (1990). Resmi ve özel liselerde çalışan öğretmenlerin iş doyumu ve iş stresine ilişkin karşılaştırmalı analizi. (Yayımlanmamış doktora tezi). İstanbul Üniversitesi Sosyal Bilimler Enstitüsü. İstanbul.

Özler, N. D. E., \& Yıldırım, H. B. (2015). Güven ile psikolojik sermaye arasındaki ilişkiyi belirlemeye yönelik bir araştırma. Nevşehir Hacı Bektaş Veli Üniversitesi SBE.Dergisi. 5, 163-188.

Pillai, R., Schriesheim, C. A., \& Williams, E. S. (1999). Fairness perceptions and trust as mediators for transformational and transactional leadership: A two-sample study. Journal of Management, 25(6), 897-933.

Platis, Ch., Reklitis, P., \& Zimeras, S. (2015). Relation between job satisfaction and job performance in healthcare services. International Conference on Strategic Innovative Marketing, IC-SIM 2014, September 1-4, 2014, Madrid, Spain. Procedia - Social and Behavioral Sciences. 175, $480-487$.

Polat, S. (2009). Eğitim örgütleri için sosyal sermaye. Örgütsel güven. Ankara: Pegem A.

Polat, S., \& Celep, C. (2008). Ortaöğretim öğretmenlerinin örgütsel adalet, örgütsel güven, örgütsel vatandaşlık davranışlarına ilişkin algıları. Kuram ve Uygulamada Eğitim Yönetimi. Bahar 2008. Sayl: 54, 307-331. 
Polat, S. (2007). Ortaöğretim öğretmenlerinin örgütsel adalet algıları, örgütsel güven düzeyleri ile örgütsel vatandaşlık davranışları arasındaki ilişki (Yayımlanmamış doktora tezi). Kocaeli Üniversitesi Sosyal Bilimler Enstitüsü. Kocaeli.

Robbins, S. (1986). Organizational behaviour. 3.nd. New Jersey. Prentice Hall.

Robbins, S. P., \& Judge, T. A. (2017). Örgütsel davranış. 14.Baskı. Çeviri i. Erdem. Nobel: Ankara.

Sancar, İ. (1996). İşletmelerde motivasyon ve iş doyumu ilişkisi. Yayınlanmamış Yüksek Lisans Tezi. Marmara Üniversitesi Sosyal Bilimler Enstitüsü. İstanbul.

Sayın, U. (2009). Güven: Iş̧letmelerde algılanan örgütsel adalet ve iş doyumu arasındaki ilişkide bir aracı-bir uygulama. (Yayımlanmamış yüksek lisans tezi). Atatürk Üniversitesi Sosyal Bilimler Enstitüsü. Erzurum.

Shockley-Zalabak, P., Ellis, K., \& Winograd, G. (2000). Organizational trust: What it means, why it matters. Organizational Development Journal, 18(4), 35-48.

Stello, C. M. (t.y). Herzberg's two-factor theory of job satisfaction: an integrative literature review. department of organizational leadership, policy and development. College of Education and Human Development. www.cehd.umn.edu/olpd/research/.../stelloherzberg.pd. adresinden 10.05.2016 tarihinde elde edilmiştir.

Stenepova, I. (2013). Manager-subordinate trust in Spain. In Manager- subordinate trust. A global perspective. Edited by P. Gardona and M.J. Morley.Routledge.Newyork and London.77-96.

Surada, S. (2015). Sınıf öğretmenlerinin iş doyum düzeyleri. (Eskişehir ili örneği). Osmangazi Üniversitesi. Sosyal Bilimler Enstitüsü. Yayınlanmamış Yüksek Lisans Tezi. Eskişehir.

Syptek, J. M., Marsland, O. W., \& Ulmer, D. (1999). Job satisfaction: Putting theory in the practice. Family Practice Management. 6(9), 26-30.

Şahin, İ. (2013). Öğretmenlerin iş doyum düzeyleri. YYü. Eğitim Fakültesi Dergisi. 10(1), 143-168.

Tamer, i. (2012). Kurumlarda bireylerarası güven. Eğitim kurumlarında bir araştırma. İstanbul Ticaret Üniversitesi Sosyal Bilimler Dergisi. 11(21). Bahar, 337-352.

Tan, H. H. \& Tan, C. (2000). Towards the differentiation of trust in supervisor and trust in organization. Genetic, Social and General Psychology Monographs. 126(2), 241-260.

Tanner, B. M. (2007). An analysis of the relationships among job satisfaction, organizational trust, and organizational commitment in an acute care hospital. The Faculty of Saybrook Graduate School and Research Center, San Francisco, California.

Tekingündüz, S., Aydın, M., \& Polat, H. (2014). Kamu sektöründe örgütsel adalet, örgütsel güven ve iş doyumu arasındaki ilişkilerin incelenmesi: Bir devlet hastanesi örneği. Sayıştay Dergisi, Sayı: 94/Temmuz-Eylül, 53-72.

Telman, N. (1988). İs doyumsuzluğu ve bunun yabancılaşma duygusu ile olan ilişkisi. (Yayımlanmamış doktora tezi). İstanbul Üniversitesi İşletme Fakültesi.

Tett, R. P., \& Meyer, J. P. (1993). Job satisfaction, organizational commitment, turnover intention and turnover: Path analysis based on meta-analytic findings. Personnel Psychology, 46(2), 259-293.

Tiffin, J. E., \& Mc Cormick, E. J. (1968). Industrial psychology. (4. Edit). New Jersey. Prentice Hall

Tunacan, S., \& Çetin, C. (2009). Lise öğretmenlerinin iş doyumunu etkileyen faktörlerin tespitine ilişkin bir araştirma. M.Ü. Atatürk Eğitim Fakültesi Eğitim Bilimleri Dergisi. Sayı: 29, 155-172

Tümkaya, S. (1996). Öğretmenlerde tükenmişlik, görülen psikolojik belirtiler ve başa çıkma davranışları. (Yayınlanmamış doktora tezi). Çukurova Üniversitesi. Adana.

Vangel, K. (2011). Employee responses to job dissatisfaction. Schmidt Labor Research Center. www.uri.edu/.../Irc/.../Vangel-Commitment.pdf. adresinden 02.03.2016 tarihinde elde edilmiştir.

Vroom, V. H. (1964). Work and motivation. John Wiley and Sons, New York, p.99.

Wech, B. (2002). Trust context: Effect on organizational citizenship behavior, supervisory fairness and job satisfaction beyond the influence of leader-member exchange. Business and Society, 41(3), 353-360.

Williams, L. L. (2005). Impact of nurses' job satisfaction on organizational trust. Health care Management Review, 30(3), $203-211$.

Yavuz, C. \& Karadeniz, C. B. (2009). Sını öğretmenlerinin iş doyumuna motivasyonu üzerine etkisi. Uluslararası Sosyal Araştırmalar Dergisi. (2)9, 507-519.

Yazıcıoğlu, í. (2009). Konaklama işletmelerinde işgörenlerin örgütsel güven duyguları ile iş doyumu ve işten ayrılma niyetleri üzerine bir alan araştirması. Elektronik Sosyal Bilimler Dergisi (Electronic Journal of Social Sciences, 8(30), 235-249.

Yıldız, K. (2013). Öğretmenlerin örgütsel adalet ve örgütsel güven algıları. AiBü Sosyal Bilimler Enstitüsü Dergisi, 13(1), $289-316$.

Yılmaz, E., (2005). Okullarda örgütsel güven ölçeğinin geçerlik ve güvenirlik çalışması. Selçuk Üniversitesi Sosyal Bilimler Enstitüsü Dergisi, (14), ss.567-580.

Yılmaz, H. ve Karahan, A. (2009). Bireylerin kişisel özellikleri yönünden iş doyum düzeylerine göre tükenmişlikleri: Afyonkarahisar ilinde bir araştırma. Süleyman Demirel Üniversitesi Iktisadi ve Idari Bilimler Fakültesi Dergisi, 14(3), 197-214.

Zaheer, A., Mc Evil, B., \& Perrone, V. (1998). Does trust matter? Exploring the effects of interorganizational and interpersonal trust on performance. Organization Science. April 1, 149-159. http://dx.doi.org/10.1287/orsc.9.2.141/ adresinden 06.06.2016 tarihinde elde edilmiştir.

Yücel, İ., \& Demirel, Y. (2013). Effects of available job alternatives on relationship between job satisfaction and intent to leave: "there must be another way, too!" Atatürk Üniversitesi Iktisadi ve Idari Bilimler Dergisi, 27(2), 159-176.

| Kastamonu Eğitim Dergisi, 27(5), 2019| 